\title{
Temperature and Relative Humidity Responses of Two Texas Cave-adapted Millipedes, Cambala speobia (Cambalida: Cambalidae) and Speodesmus Bicornourus (Polydesmida: Vanhoeffeniidae)*
}

\author{
by
}

\author{
Eddie BULL and Robert W. MITCHELL**
}

\section{INTRODUCTION}

The purposes of this research were to determine the preference responses and tolerances of two cave-adapted millipedes, Cambala speobia (Chamberlin) and Speodesmus bicornourus Causey, to relative humidity and temperature and to attempt to relate these responses to the distribution and evolution of the two species.

Very few quantitative studies have been made on the preference responses of invertebrate cavernicoles to physical factors in the environment. No such date at all have been published on preference responses to relative humidity. C. L. Edwards (pers. comm. based upon unpublished data) reports that a cavernicole ricinuleid, Cryptocellus pelaez $i$, show directed response in a humidity gradient by moving rapidly to areas of saturation. Mitchell (1971b) reports that the troglobite (obligate cavernicole) carabic beetle Rhadine subterranea also prefers saturated atmospheres over lower relative humidities and suggests that this preference is one mechanism that restricts the animal to its subterranean environment. Vandel (1965) has agreed with Jeannel (1943) that all troglobites are stenohygrobic and extremely sensitive to drying. But Poulson (1964) has stated that the assumption of stenohygroby for troglobites is based only on the circumstantial evidence that they occur in nearsaturated atmospheres with little air movement.

Likewise, very little work on the temperature responses of troglobites has been done. Szymckowsky (1953) found that Meta menardi, a troglophile spider, showed an activity optimum of $6^{\circ}$ to $8^{\circ} \mathrm{C}$. Mitchell $(1971 \mathrm{~b})$ reported that Rhadine subterranea shows a seasonal shift in its temperature preferendum, selecting a higher temperature in winter than in summer, with a winter preference approximating cave temperature. This is interpreted as a partial restrictive mechanism aiding in limiting the animals to the cave, but providing potential for emigration from the subterranean environment during that time of the year when the chances for survival would be best. Cryptocellus pelaezi shows a tactic response in a temperature gradient, selecting $28^{\circ} \mathrm{C}$ almost immediately (Edwards, pers. comm.).

\footnotetext{
* Assisted by State-appropriated research funds administered by the Graduate School, Texas Tech University.

** Department of Biology and The Museum, Texas Tech University, Lubbock, Texas.
} 


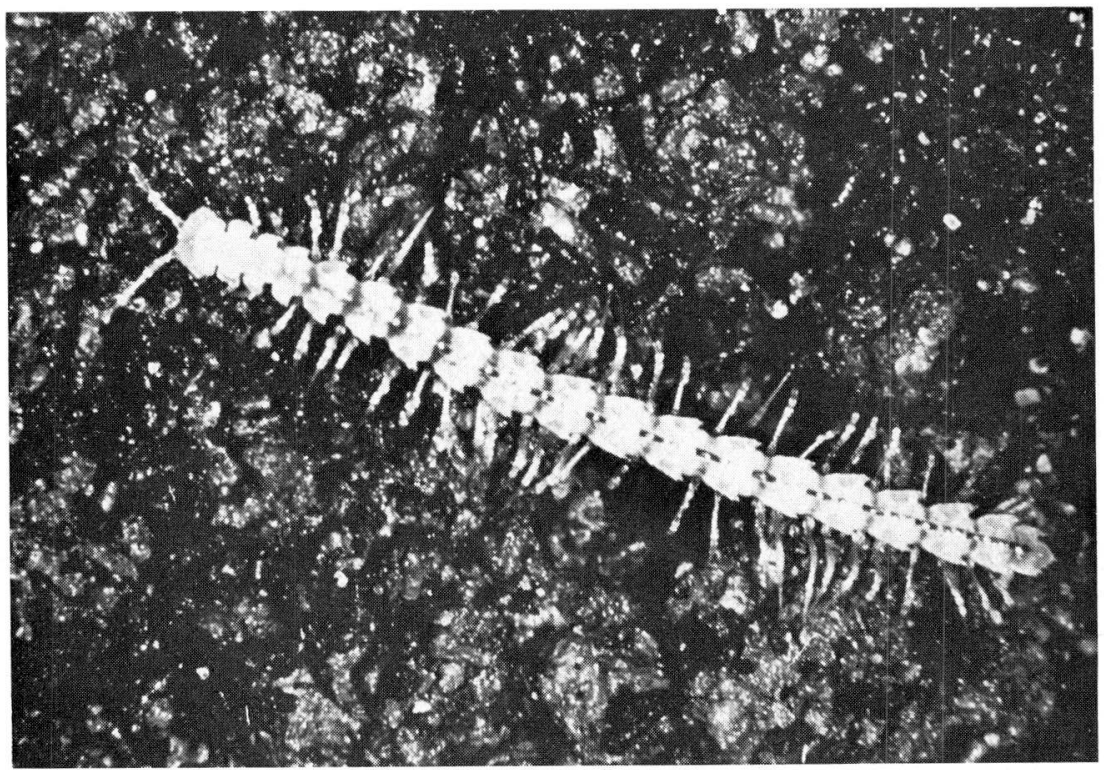

Fig. 1. Speodesmus bicornourus

Vandel (1965) cites P. de Beauchamp (1932) as saying that cavernicole planarians which he maintained in the laboratory were not strict stenotherms. Some withstood temperatures of $25^{\circ}$ to $28^{\circ} \mathrm{C}$ if the rise was not too rapid and the medium not too confining. Similarly, another cavernicole, an amphipod Niphargus sp., can survive temperatures of $24.5^{\circ} \mathrm{C}$, although the optimum is $8^{\circ}$ to $14^{\circ} \mathrm{C}$ (Ginet, 1960). This upper limit of tolerance coincides closely with the upper lethal temperature of surface relatives. Glaçon (1953) found the beetle Speonomus diecki, another troglobite, to be capable of surviving temperatures of $25^{\circ} \mathrm{C}$, indicating that it, too, could not be considered a strict stenotherm. In summary, Vandel (1965) states that stenothermia in troglobites is not an established fact.

The genus Speodesmus Loomis is represented by two described species and a few undescribed ones, all of which are known only from caves of central Texas (Causey, 1959; Chamberlin and Hoffman, 1958; pers. comm., Causey to Reddell). Speodesmus bicornourus Causey (Fig. 1) has been found in Travis, Lampasas, and Williamson Counties (Reddell, 1965, 1970). This millipede is a highly adapted troglobite, this reflected in its almost total depigmentation and attenuated antennae and legs (Causey, 1959). It is also eyeless but so are all other polydesmid species, most of which are epigean. Distributions of all species of Speodesmus are shown in Fig. 3.

The genus Cambala is a major element in the millipede fauna of the forests of the eastern United States where it is represented by several species. Its epigean distribution reaches into eastern Texas, but in central Texas it is restricted to caves and represented by only a single species (Causey, 1964), Cambala speobia (Cham- 


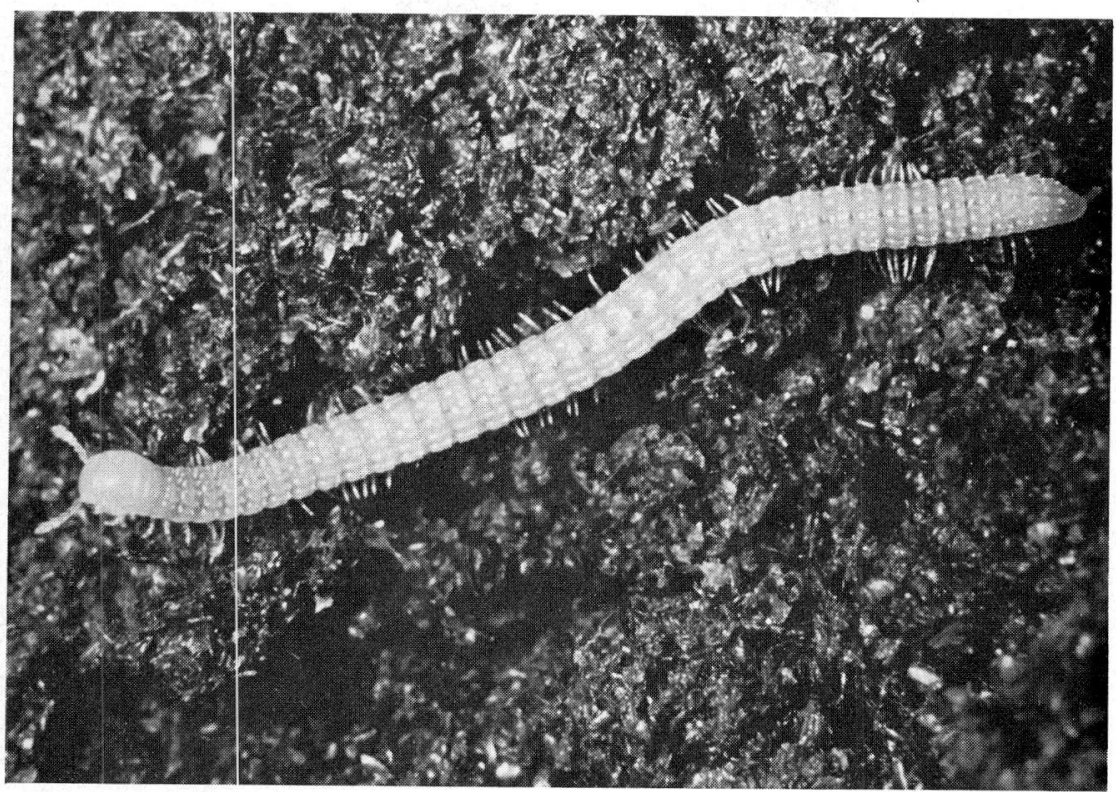

Fig. 2. Cambala speotia

berlin) (Fig. 2). C. speobia is widely distributed throughout several counties of central Texas (Fig. 4), and is so frequent in the caves of this area that it is commonly called the "Texas Blind Millipede" (Causey, 1959). Anophthalmia is the only striking morphological adaptation to a cavernicole existence in C. speobia, since it retains some pigmentation, and its legs and antennae are only slightly lengthened. In the eastern United States, cambalids are usually found only occasionally in cave entrance areas, but one troglobite is known, $C$. loomisi (Hoffman) occurring in an Alabama cave (Causey, 1964, pers. comm.). C. reddelli inornatus of gypsum caves of northwest Texas is also thought to be a troglobite (Causey, 1964).

All millipe des used in this research were taken from caves in close proximity in Travis and Williamson Counties. Original plans called for restricting collections to Beck's Ranch Cave, (Mitchell, 1971a) in Williamson County, but a scarcity of specimens prevented this. Nearly all cambalids and many S. bicornourus were taken from this cave, however. The remaining individuals were taken from Tooth Cave and Kretschmarr Cave nearby in Travis County.

All of these caves are formed in Edwards limestone. Temperatures vary little from approximately $20^{\circ} \mathrm{C}$. No deviations from saturation in Beck's Ranch Cave were detected by a sling psychrometer (Mitchell, 1971a), but observations made at different times of the year indicate that relative humidity must at times drop below $100 \%$, for the substrate in the cave becomes noticeably drier during the summer months. 


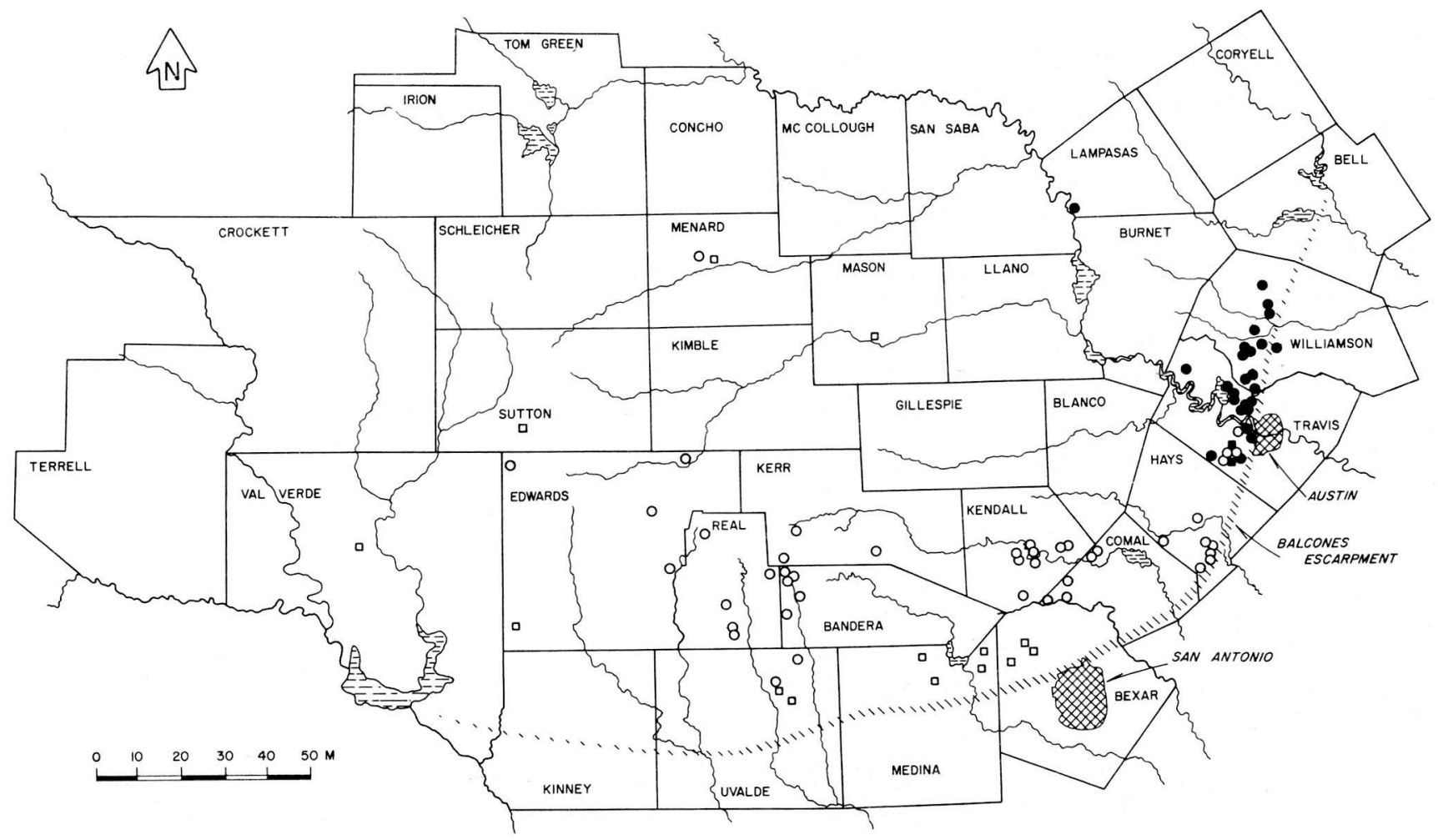

Fig. 3. Distribution of Speodesmus in central Texas. •, S. bicornourus; O, S. echinourus; $\mathbf{m}$, both S. bicornourus and $S$. echinourus; $\square$, undescribed and undetermined species. One record of unknown location in Hays County not plotted. 


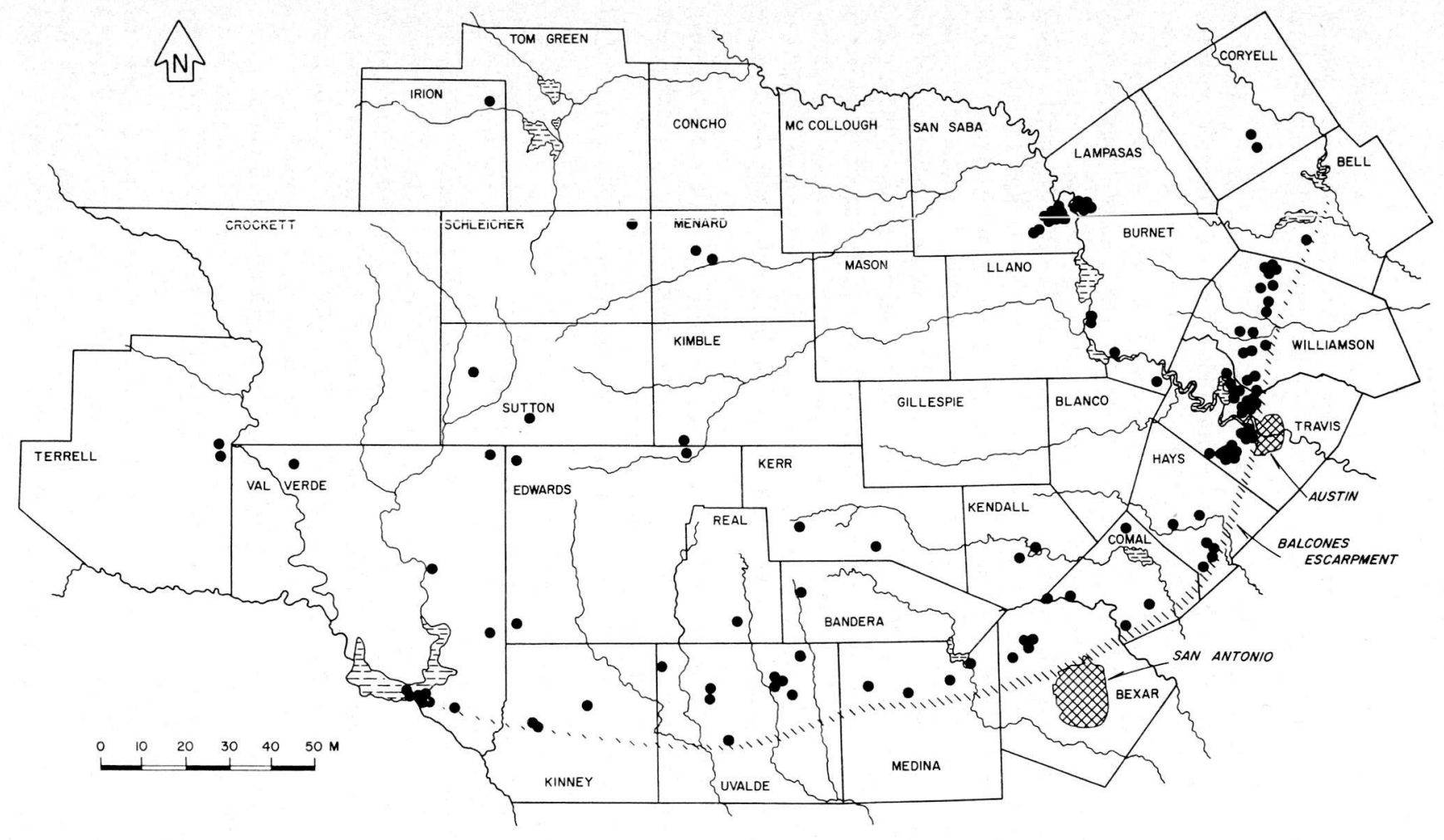

贷

Fig. 4. Distribution of Cambala speobia in central Texas. Not plotted are records of unknown location, one each, in Edwards and Kimble Counties. 


\section{MATERIALS AND METHODS}

Several collecting attempts were made, but each yielded rather small samples. No attempt was thus made to segregate the animals according to locality or date of collection because of the rather large sample size required by the experimental design.

Cambala speobia occurs on cave floors, walls, and ceilings. Many of these millipedes were collected as they fell from the ceiling when illuminated with the beam of a flashlight, a result of their well developed coiling response. Speodesmus bicornourus is more commonly found on the floor of the cave, and it frequently cohabits areas with $C$. speobia. It does not exhibit the coiling response of $C$. speobia, but it does appear to be photonegative.

The cambalids were kept in the laboratory without difficulty in tightly sealed polyethylene containers provided with moistened paper toweling and a humus rich soil. In experiments which required observations of a group of millipedes for several weeks, the soil was omitted to facilitate counting, and animals under these conditions remained hardy for months, feeding upon the toweling. S. bicornourus, on the other hand, proved more difficult to maintain. Tolerance data show them to be more sensitive to temperature changes than $C$. speobia, and this probably accounts for the difficulty in both transporting these animals from the cave to the laboratory and in maintaining them in the laboratory. Although $S$. bicornourus would live for several months on the paper toweling, there was no evidence that the toweling was eaten.

Laboratory temperature was maintained as near to $20^{\circ} \mathrm{C}$ as possible, but because of inadequate temperature controlling facilities, the temperature occasionally rose and fell $2^{\circ}$ to $3^{\circ} \mathrm{C}$. from the desired temperature.

The materials and methods of the individual experiments will be elaborated specifically as follows.

\section{Preference Experiments}

Relative humidity. A linear gradient chamber constructed of 1/8 inch Plexiglas was used in determining humidity preferences (Fig. 5). The apparatus consisted essentially of a tightly sealed rectangular box divided by a substrate into upper and lower chambers. The substrate was made of fused, hardened polyethylene chips, molded into a sheet $1 / 8$ inch thick and having a pore size of approximately $70 \mu$. The lower chamber was partitioned by vertical Plexiglas walls to form ten compartments. The lid of the apparatus was fitted with eleven El-tronics, Model 2C-B, hygroscopic sensors equally spaced so as to delineate ten areas in the upper chamber. These areas of known relative humidity range were used in data recording and were numbered 1 - 10 from left to right.

The humidity gradient was established by adding 95\% glycerol to the end compartments (numbers 9 and 10) of the lower half and distilled water to compartments $3-8$ inclusive. The substrate was carefully positioned to insure that it did not come into contact with any of the solutions. The lid was replaced, and 

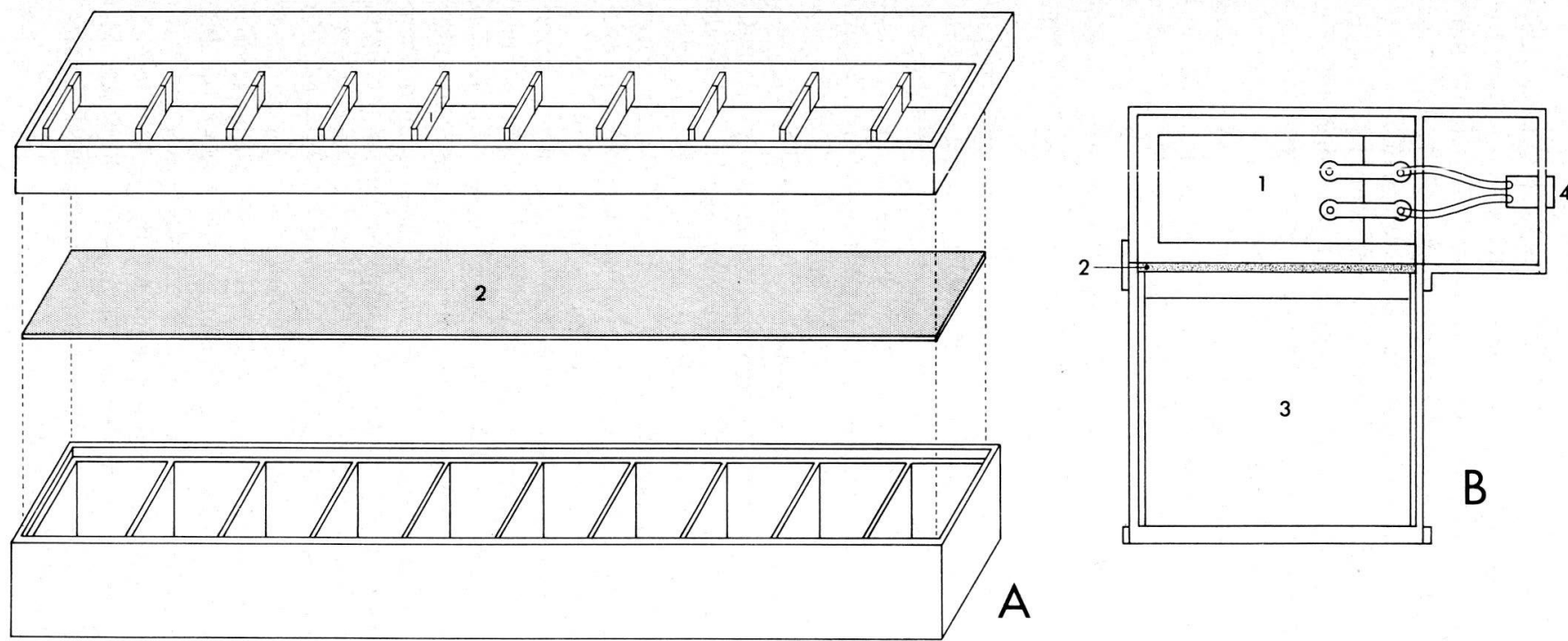

A

Fig. 5. Relative Humidity Preference Apparatus. A. Exploded view of the gradient chamber. B. Cross section of assembled chamber. 1, sensor. 2, substrate. 3, compartment for glycerol solution or water. 4, connector for lead to readout system (not shown). Inside dimensions of lid, the actual housing for the experimental animals, $60 \mathrm{~cm} \mathrm{X} 6 \mathrm{~cm} \mathrm{X} 3 \mathrm{~cm}$. Sensors spaced at $6 \mathrm{~cm}$ intervals. Other details in text. 
within two hours the desired gradient was stabilized. Relative humidities detected by each sensor were read with an El-tronics Model 102 electronic hygrometer equipped with an 11-point switchbox. Sensor accuracy was $\pm 2 \%$ relative humidity over most of the range, but decreased to $5 \%$ in the upper range; e.g., a relative humidity higher than $95 \%$ could not be reliably separated from $100 \%$.

After the gradient was established, four male and four female cambalids were placed in the chamber, two of each sex through each of two holes in the lid (in areas 3 and 8 ). Their positions were recorded at five minute intervals for a duration of two hours, beginning 30 minutes after their introduction. All censuses were made in a darkened room with a light shield being removed only long enough to record the animals' positions. A handlight was used to view the animals at this time. Six runs were made, vielding a total of 1152 position-records based upon the responses of 48 individuals.

Limited numbers of Speodesmus bicornourus made the testing of equal numbers of each sex impossible. Otherwise, the methods of testing this species were the same as for Cambala speobia.

Controls for each species were run after completion of the experimental runs. Distilled water was added to each compartment to establish a continuous saturated atmosphere within the chamber, The methods of data gathering then proceeded as in the experimental runs. In the control runs of S. bicornourus, two animals died while within the chamber, reducing the total number of position-records accordingly.

Temperature. As with the relative humidity preference chamber, a tightly sealed rectangular Plexiglas chamber was used in determining temperature preferenda (Fig. 6). This chamber was delineated into 12 areas by 13 equally spaced YSI Model 401 thermistor sensors inserted through gasketed holes in the lid of the chamber. The probe tips were positioned one millimeter above the substrate. This experimental chamber was fitted into an open aluminum channel which had one end enclosed, forming a water-tight container through which coolant circulated.

The temperature gradient was established by heating one end of the channel and cooling the other. The cooling employed an external water bath containing ethylene glycol maintained at a temperature of $0^{\circ} \mathrm{C}$ by a refrigeration unit, the compressor of which was activated by a YSI Mode1 71 Thermistemp temperature controller. The coolant was pumped through the enclosed portion of the aluminum channel at the "cold" end of the chamber by a circulating pump located in the bath. The coolant reduced the temperature at this end of the chamber a few degrees below the set-point. To bring the temperature up to the desired $10^{\circ} \mathrm{C}$, three 250 -watt strip heaters were fixed to the "cold" end of the aluminum channel. Voltage input into the heaters was regulated by an Athena Model 51 proportional temperature controller responding to a thermistor probe located in the end of the Plexiglas experimental chamber. The "hot" end of the channel was equipped with one 250-watt heater. Here again, heater output was regulated by an Athena Model 51 controller whose sensing probe was located in the other end of the Plexiglas experimental chamber. Temperatures sensed by each probe were read directly using a 12-channel YSI Model 44TD telethermometer. 
The aluminum channel with its Plexiglas insert was housed in a plywood case and was insulated with 2-inch polystyrene foam.

It was impossible to maintain the air within the chamber at $100 \%$ relative humidity without saturating the substrate (made of the same material as that used in the relative humidity preference chamber) with distilled water. The saturation was accomplished by placing the substrate in contact with distilled water of $3 \mathrm{~mm}$

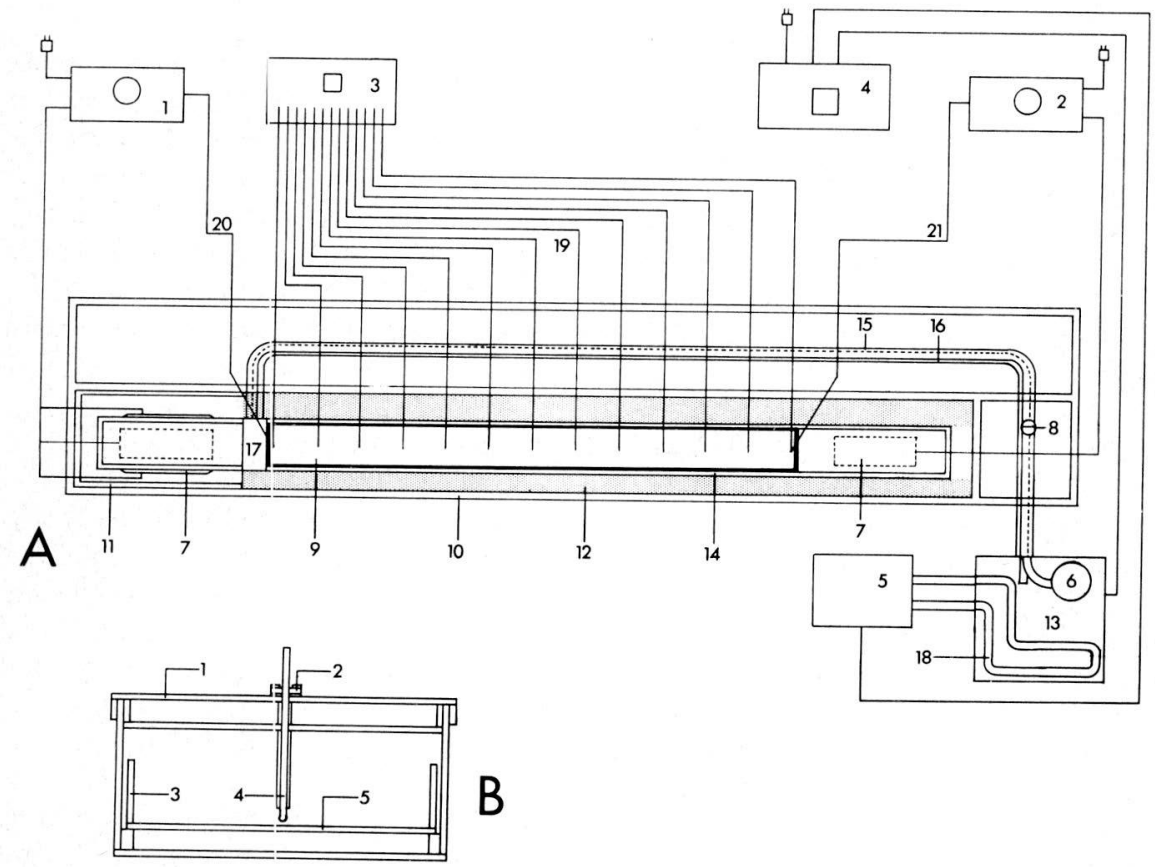

Fig. 6. Temperature Preference Apparatus, semi-schematic. A. View from above of the gradient chamber and associated equipment. 1, cold end controller. 2, hot end controller. 3, temperature readout apparatus. 4, cold bath controller. 5, refrigeration unit for chilling cold bath. 6 , pump for circulating chilled water to gradient chamber. 7 , strip heaters. 8 , valve for regulating cold water flow. 9, Plexiglas insert, the actual housing for the experimental animals. 10, wooden housing for gradient chamber and closely associated parts. 11 , asbestos sheeting protecting housing from heat. 12, polystyrene foam insulation. 13, cold water bath. 14, aluminum channel, the heat transferrer, housing the Plexiglas insert. 15, cold water input conduit. 16, cold water return conduit. 17, cold water compartment for chilling the aluminum channel. 18, cooling coil. 19, sensor leads from chamber to readout. 20, sensor lead from chamber to cold end controller. 21, sensor lead from chamber to hot end controller. Internal dimensions of the Plexiglas insert, $120 \mathrm{~cm} \mathrm{X} 12 \mathrm{~cm} \mathrm{X} 5 \mathrm{~cm}$. Thermistorized sensors spaced at $10 \mathrm{~cm}$ intervals. B. Cross section through Plexiglas insert. 1, lid containing dead air space. 2, gasket providing seal around sensor lead. 3, false wall preventing animal contact with true wall where differential condensation might provide a source of bias. 4 , sensor. 5 , substrate. Other details in text. 
depth in the bottom of the chamber. This water reduced the speed of the millipedes' movement compared to that on the drier substrate of the relative humidity chamber, but two reasons dictated this water requirement: 1) the animals live in a saturated or near-saturated environment, and 2) unless the atmosphere is maintained at either $100 \%$ or $0 \%$ relative humidity, a relative humidity gradient becomes superimposed upon the temperature gradient, making it impossible to separate the response to temperature alone. The reduction in speed did not affect the animals' ability to traverse the length of the chamber within the five minute recording interval.

Cambalids were sexed and tested in four groups of 12 each, six males and six females. One-half of each group was introduced into the chamber through a hole in the lid above area 4; the other one-half through a hole above area 9. Speodesmus bicornourus was tested in the same way except that individuals were not sexed.

Control experiments were conducted with the entire apparatus stabilized at a constant ambient temperature of $20^{\circ} \mathrm{C}$. The millipedes used in these control runs were the same as those used in the experimental runs. One control group had fewer position-records due to the death of a millipede between experimental and control runs.

\section{Tolerance Experiments}

Relative humidity. The apparatus used for testing relative humidity tolerances is described elsewhere by Mitchell (1971b). It consisted of a battery of six Plexiglas cells, each of which could be tightly sealed. Each cell contained a jar of sulfuric acid to maintain the desired humidity, a tray to contain the specimens, and a sealable tube which allowed introduction of the millipedes to the chamber after the desired humidity was established. The sulfuric acid was used in these studies, since it is much easier to establish a desired relative humidity with it rather than with the glycerol used in the preference chamber.

The temperature in the individual cells was held constant at $20^{\circ} \mathrm{C}$ by suspending the entire apparatus in a temperature controlled water bath. Twenty male and twenty female cambalids were tested by separate sex in two groups of ten individuals each. These were exposed to the different relative humidities for a period of 12 hours, this interval being a rather arbitrary one arrived at by some trial-and-error preliminary experimentation. Speodesmus bicornourus were tested as above except that no sex distinction was made and exposure was limited to four hours. $C$. speobia was exposed to $25 \%, 50 \%$, and $75 \%$ relative humidity; $S$. bicornourus only to $50 \%$. Each species was also exposed in a similar fashion to $100 \%$ relative humidity as a control.

Temperature. No special apparatus was constructed for these experiments. The basic piece of equipment used was a Chicago Surgical and Electrical Model 13000 paraffin bath which held temperatures within specimen jars constant to within \pm $1 / 2^{\circ} \mathrm{C}$ of the desired testing temperature. A triple layer of paper toweling saturated with distilled water was placed in the bottom of each jar to maintain saturation, 
and a mercury thermometer was used to determine air temperature inside the jars. A disadvantage of this procedure lay in the necessity to open the jars momentarily to admit the millipedes. This was done quickly, but temperatures dropped about $1^{\circ}$, and it took about five minutes for them to regain their former level. Water of condensation was also a problem, with free water occasionally being present in the bottom of the jars. But since heat transfer between water and animals would be more rapid than that between air and animal, the data obtained would be an underestimate of survival rather than an overestimate.

Twenty male cambalids, 20 female cambalids, and 20 individuals of Speodesmus bicornourus were tested at temperatures of $30^{\circ} \mathrm{C}$ and $35^{\circ} \mathrm{C}$. C. speobia was exposed for 24 hours at $30^{\circ} \mathrm{C}$ and 7 hours at $35^{\circ} \mathrm{C}$, while $S$. bicornourus was exposed for 15 hours at $30^{\circ} \mathrm{C}$ and 45 minutes at $35^{\circ} \mathrm{C}$. At the end of the exposure time, the animals were removed to polyethylene containers and maintained at saturation and an ambient temperature to approximately $20^{\circ} \mathrm{C}$. Numbers of survivors were counted $24,36,48,60,72,96,240$, and 600 hours after termination of the experiments. An animal was recorded as a survivor if it could move any body part. However, most survivors showed apparently normal motility.

\section{RESULTS}

\section{Preference Experiments}

Relative humidity. Fig. 7 shows graphically the numbers of occurrences of Cambala speobia and of Speodesmus bicornourus in each of the 10 areas of the relative humidity gradient chamber for both the experimental and control runs. Casual observation of the graphs indicates striking differences between experimental and control data of each species. Contingency table analyses of the data further demonstrate the differences with $P$ values much less than .001 (Table 1).

Both species showed a preference for atmospheres at or near saturation. However, over $66 \%$ of the cambalid occurrences were in those four areas representing the $95 \%-100 \%$ relative humidity range while only $48 \%$ of the S. bicornourus occurrences were within this range. This difference is significant at $\mathrm{P}<.001$ (Table 2). Thus $C$. speobia has a stronger preference for the higher relative humidities than does $S$. bicornourus.

Neither species appeared to show a directed response when exposed to the gradient. Neither do the experimental data reflect repeated records of motionless animals. Rather, there was almost continual movement except in some control runs when the end areas were frequently occupied for intervals up to thirty minutes by groups of three or four individuals. This effect of an additional edge in the end areas is of common occurrence in linear gradient chambers (Perttunen, 1953; Mitchell, 1971b). The experimental runs were not entirely free from this source of bias, as the graphs in Fig. 7 demonstrate. 

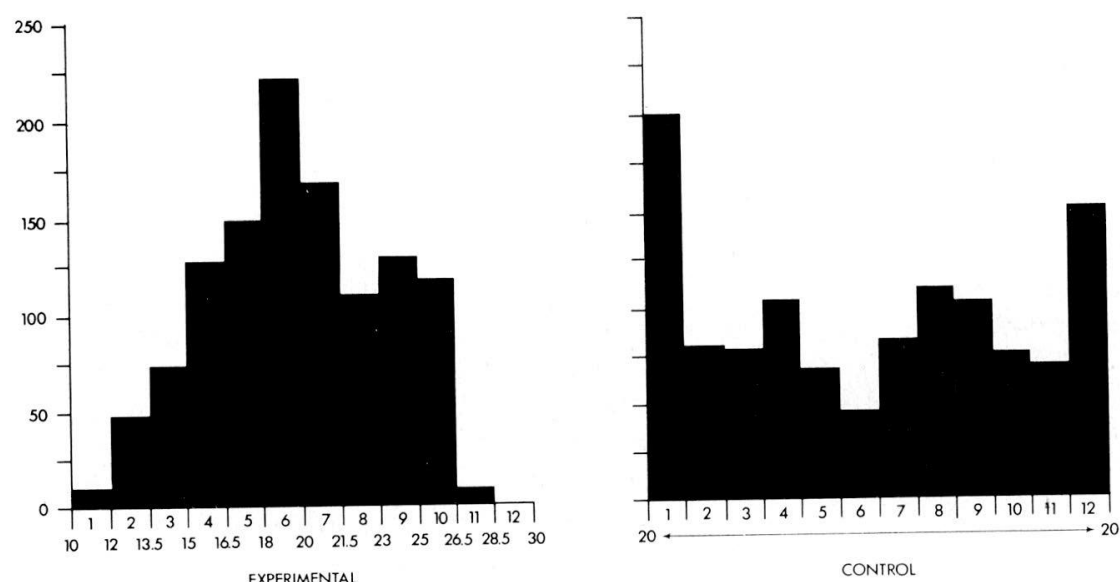

\section{Cambala speobia}
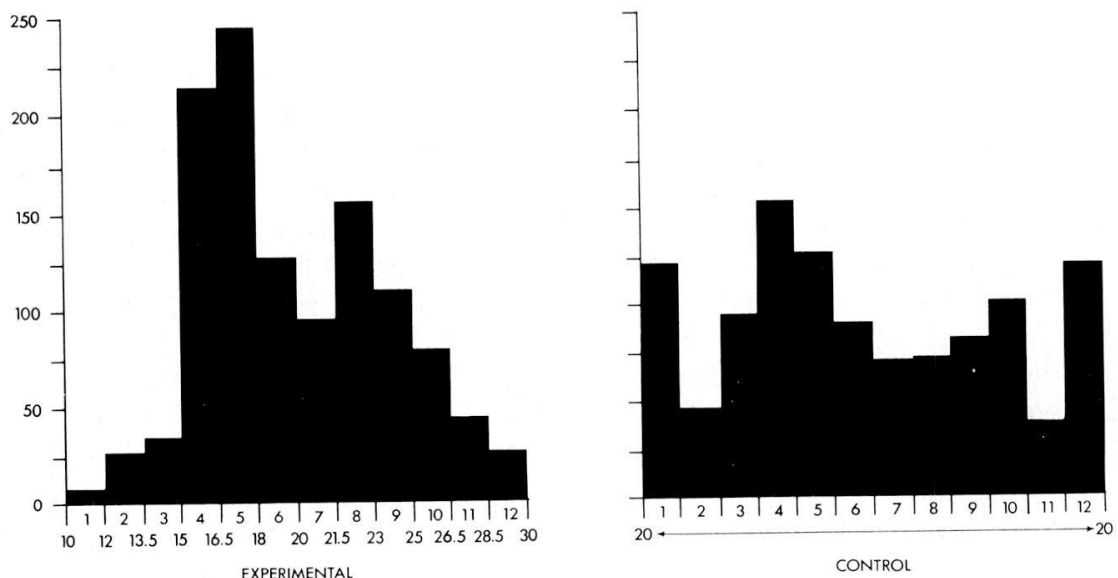

Speodesmus bicornourus

Fig. 7. Graphs of Relative Humidity Preference Data. Ordinates show numbers of animal occurrences in the different areas of the gradient chamber. Abscissae show chamber area designations (first row) and the relative humidities sensed at the boundaries of the recording areas (second row). 
TABLE 1. Contigency table analyses of relative humidity preference data. Compared are numbers of animal occurences in the different areas of the gradient chamber.

Area of Chamber

$\begin{array}{lccccccccccc}\begin{array}{l}\text { C. speobia, } \\ \text { experimental }\end{array} & 81 & 38 & 82 & 254 & 198 & 194 & 117 & 79 & 37 & 72 & 1152 \\ \begin{array}{l}\text { C. speobia, } \\ \text { control }\end{array} & 2.56 & 70 & 55 & 81 & 46 & 108 & 86 & 56 & 126 & 268 & 1152 \\ & \chi^{2} / 9 & \text { d.f. }= & 484.43, \mathrm{P}<.001 & & & & & & \end{array}$

$\begin{array}{llllllllllll}\begin{array}{l}\text { S. bicornourus, } \\ \text { experimental }\end{array} & 138 & 46 & 92 & 138 & 153 & 141 & 125 & 101 & 70 & 148 & 1152\end{array}$

$\begin{array}{llllllllllll}\begin{array}{l}\text { S. bicornourus, } \\ \text { control }\end{array} & 253 & 92 & 117 & 77 & 56 & 58 & 71 & 65 & 122 & 193 & 1104\end{array}$ $\chi^{2} / 9$ d.f. $=190.86, \mathrm{P}<.001$

$\begin{array}{llllllllllll}\begin{array}{l}\text { S. bicornourus, } \\ \text { experimental }\end{array} & 138 & 46 & 92 & 138 & 153 & 141 & 125 & 101 & 70 & 148 & 1152\end{array}$

C. speobia, experimental

$$
\begin{array}{lllllllllll}
81 & 38 & 82 & 254 & 198 & 194 & 117 & 79 & 37 & 72 & 1152 \\
\chi^{2} / 9 & \text { d.f. }= & 104.04, \mathrm{P}<.001
\end{array}
$$

$\begin{array}{llllllllllll}\begin{array}{l}\text { S. bicornourus, } \\ \text { control }\end{array} & 253 & 92 & 117 & 77 & 56 & 58 & 71 & 65 & 122 & 193 & 1104\end{array}$

$\begin{array}{llllllllllll}\begin{array}{l}\text { C. speobia, } \\ \text { control }\end{array} & 256 & 70 & 55 & 81 & 46 & 108 & 86 & 56 & 126 & 268 & 1152\end{array}$ $\chi^{2} / 9$ d.f. $=54.75, \mathrm{P}<.001$ 
TABLE 2. Comparison of occurrences within and outside the $95 \%-100 \%$ relative humidity range.

\begin{tabular}{|c|c|c|}
\hline & Within & Outside \\
\hline $\begin{array}{l}\text { C. speobia, } \\
\text { experimental }\end{array}$ & 763 & 389 \\
\hline \multirow{2}{*}{$\begin{array}{l}\text { C. speobia, } \\
\text { control }\end{array}$} & 321 & \multirow[t]{2}{*}{831} \\
\hline & $\chi^{2} / 1$ d.f. $=338.73, P<.001$ & \\
\hline $\begin{array}{l}\text { S. bicornourus, } \\
\text { experimental }\end{array}$ & 557 & 595 \\
\hline \multirow{2}{*}{$\begin{array}{l}\text { S. bicornourus, } \\
\text { control }\end{array}$} & 262 & \multirow[t]{2}{*}{842} \\
\hline & $\chi^{2} / 1$ d.f. $=146.70, \mathrm{P}<.001$ & \\
\hline $\begin{array}{l}\text { C. speobia, } \\
\text { experimental }\end{array}$ & 763 & 389 \\
\hline \multirow{2}{*}{$\begin{array}{l}\text { S. bicornourus, } \\
\text { experimental }\end{array}$} & 557 & \multirow[t]{2}{*}{595} \\
\hline & $\chi^{2} / 1$ d.f. $=74.55, \mathrm{P}<.001$ & \\
\hline $\begin{array}{l}\text { C. speobia, } \\
\text { control }\end{array}$ & 321 & 831 \\
\hline \multirow{2}{*}{$\begin{array}{l}\text { S. bicornourus, } \\
\text { control }\end{array}$} & 262 & \multirow[t]{2}{*}{842} \\
\hline & $\chi^{2} / 1$ d.f. $=4.810, P<.05$ & \\
\hline
\end{tabular}

Temperature. Fig. 8 shows occurrences of the millipedes in the areas of the temperature gradient chamber for experimental and control runs. Again, sufficient differences in control and experimental data for both species were demonstrated by contingency table analysis $(\mathrm{P}<.001$; Table 3$)$. It is seen in Fig. 8 that the temperature preferendum of each species may be regarded as $15^{\circ} \mathrm{C}$ to $26.5^{\circ} \mathrm{C}$. The preferendum of $C$. speobia is most defined at the higher temperature, while that of $S$. bicornourus is more sharply defined at the lower temperature. Table 4 shows that there is no significant difference $(\mathrm{P}>.75)$ between the two species in the intensities of their responses to the preferred range (i.e., in numbers of occurrences within vs. numbers of occurrences outside of $15^{\circ} \mathrm{C}$ to $26.5^{\circ} \mathrm{C}$ ). There is, however, a significant difference in the responses of the two species when their distribution in 

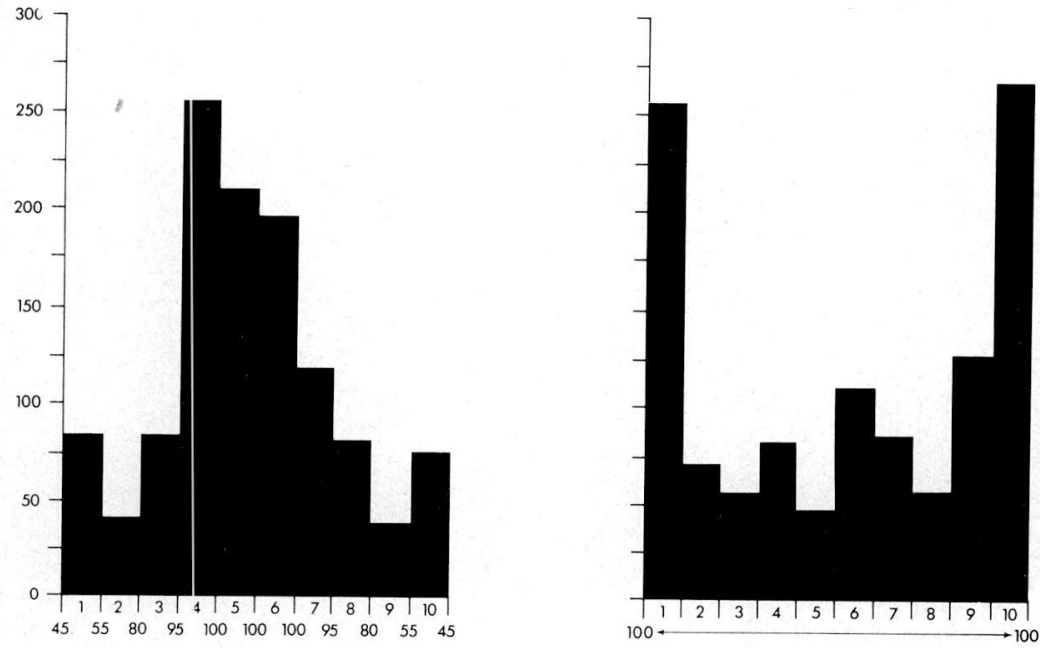

EXPERIMENTAL

CONTROL

\section{Cambala speobia}

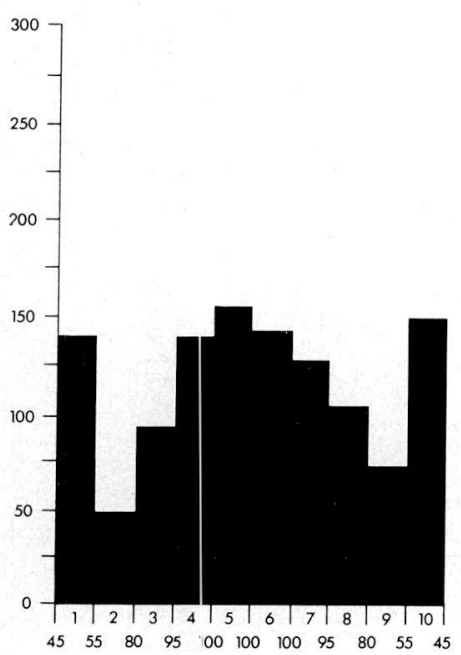

EXPERIMENTAL

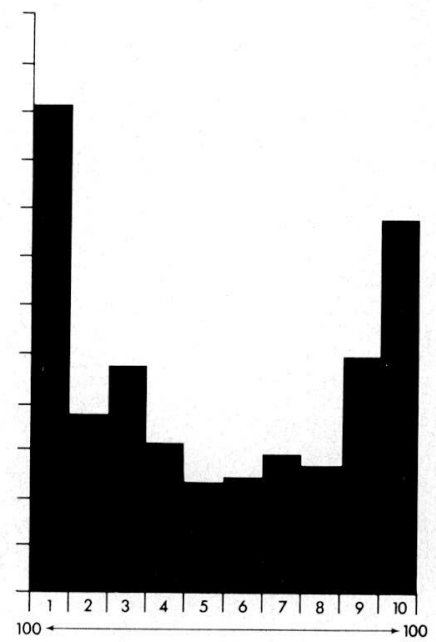

CONTROL

\section{Speodesmus bicornourus}

Fig. 8. Graphs of Temperature Preference Data. Ordinates show numbers of animal occurrences in the different areas of the gradient chamber. Abscissae show chamber area designations (first row) and the temperatures sensed at the boundaries of the recording areas (second row). 
TABLE 3. Contingency table analyses of temperature preference data. Shown are numbers of animal occurrences in the different areas of the gradient chamber.

Area of Chamber

\begin{tabular}{|c|c|c|c|c|c|c|c|c|c|c|c|c|c|}
\hline \multicolumn{14}{|c|}{ Area of Chamber } \\
\hline & 1 & 2 & 3 & 4 & 5 & 6 & 7 & 8 & 9 & 10 & 11 & 12 & Total \\
\hline $\begin{array}{l}\text { C. speobia, } \\
\text { experimental }\end{array}$ & 9 & 47 & 73 & 126 & 148 & 222 & 166 & 109 & 128 & 116 & 8 & 0 & 1152 \\
\hline \multirow{2}{*}{$\begin{array}{l}\text { C. speobia, } \\
\text { control }\end{array}$} & 200 & 77 & 76 & 104 & 68 & 45 & 78 & 110 & 102 & 74 & 68 & 150 & 1152 \\
\hline & \multicolumn{13}{|c|}{$\chi^{2} / 11$ d.f. $=572.26, \mathrm{P}<.001$} \\
\hline $\begin{array}{l}\text { S. bicornourus, } \\
\text { experimental }\end{array}$ & 7 & 26 & 32 & 213 & 246 & 126 & 94 & 155 & 109 & 77 & 42 & 25 & 1152 \\
\hline \multirow{2}{*}{$\begin{array}{l}\text { S. bicornourus, } \\
\text { control }\end{array}$} & 122 & 48 & 96 & 155 & 128 & 92 & 70 & 74 & 84 & 101 & 37 & 121 & 1128 \\
\hline & \multicolumn{13}{|c|}{$\chi^{2} / 11$ d.f. $=93.75, P<.001$} \\
\hline $\begin{array}{l}\text { S. bicornourus, } \\
\text { experimental }\end{array}$ & 7 & 26 & 32 & 213 & 246 & 126 & 94 & 155 & 109 & 77 & 42 & 25 & 1152 \\
\hline \multirow{2}{*}{$\begin{array}{l}\text { C. speobia, } \\
\text { experimental }\end{array}$} & 9 & 47 & 73 & 126 & 148 & 222 & 166 & 109 & 128 & 116 & 8 & 0 & 1152 \\
\hline & \multicolumn{13}{|c|}{$\chi^{2} / 11$ d.f. $=180.94, P<.001$} \\
\hline $\begin{array}{l}\text { S. bicornourus, } \\
\text { control }\end{array}$ & 122 & 48 & 96 & 155 & 128 & 92 & 70 & 74 & 84 & 101 & 37 & 121 & 1128 \\
\hline \multirow[t]{2}{*}{$\begin{array}{l}\text { C. speobia, } \\
\text { control }\end{array}$} & 200 & 77 & 76 & 104 & 68 & 45 & 78 & 110 & 102 & 74 & 68 & 150 & 1152 \\
\hline & \multicolumn{13}{|c|}{$\chi^{2} / 11$ d.f. $=97.85, P<.001$} \\
\hline
\end{tabular}


the different areas of the preferred range are compared $(\mathrm{P}<.001$, Table 5). This difference results from a unimodal response of $C$. speobia and a bimodal response of $S$. bicornourus where, in the latter, cave temperature lies between the two modes. Consequently, when the responses of the two millipedes are compared. based upon the numbers of occurrences in those two areas most closely approximating cave temperature (areas 5 and $6,18^{\circ} \mathrm{C}$ to $21.5^{\circ} \mathrm{C}$ ) vs. numbers of occurrences outside this range, a marked difference is apparent (Table 6). No directed movements were apparent in the temperature gradient, and the millipedes moved freely throughout the chamber. Thus, the bimodal distribution of occurrences of $S$. bicornourus was not the result of limited movement from the two points of their introduction into the chamber. Control run data show the presence of end effect bias, but experimental run data do not, as do the experimental run data from the relative humidity gradient chamber. This suggests a more rapid response to temperature than to relative humidity since the preference for an edge was overridden more rapidly by an unpreffered temperature than by an unpreferred relative humidity.

TABLE 4. Comparison of animal occurrences within and outside the $15^{\circ}-26.5^{\circ}$ temperature range.

\begin{tabular}{|c|c|c|}
\hline & $\begin{array}{c}\text { Within } \\
\text { range }\end{array}$ & $\begin{array}{l}\text { Outside } \\
\text { range }\end{array}$ \\
\hline C. speobia, experimental & 1015 & 137 \\
\hline \multirow[t]{2}{*}{ C. speobia, control } & 581 & 571 \\
\hline & \multicolumn{2}{|c|}{$\chi^{2} / 1$ d.f. $=38.23, \mathrm{P}<.001$} \\
\hline S. biconourus, experimental & 1020 & 132 \\
\hline \multirow[t]{2}{*}{ S. bicornourus, control } & 704 & 424 \\
\hline & \multicolumn{2}{|c|}{$\chi^{2} / 1$ d.f. $=20.962, \mathrm{P}<.001$} \\
\hline C. speobia, experimental & 1015 & 137 \\
\hline \multirow[t]{2}{*}{ S. bicornourus, experimental } & 1020 & 132 \\
\hline & \multicolumn{2}{|c|}{$\chi^{2} / 1$ d.f. $=.067, P>.75$} \\
\hline C. speobia, control & 581 & 571 \\
\hline \multirow[t]{2}{*}{ S. bicornourus, control } & 704 & 424 \\
\hline & \multicolumn{2}{|c|}{$\chi^{2} / 1$ d.f. $=3.201, \mathrm{P}>.05$} \\
\hline
\end{tabular}


TABLE 5. Contingency table analyses based upon numbers of animal occurences in the different areas represented in the $15^{\circ} \mathrm{C}-26.5^{\circ} \mathrm{C}$ temperature range of the gradient chamber.

\begin{tabular}{lccccccc}
\hline & \multicolumn{7}{c}{ Area of Gradient Chamber } \\
& 4 & 5 & 6 & 7 & 8 & 9 & 10 \\
\cline { 2 - 7 } & 126 & 148 & 222 & 166 & 109 & 128 & 116 \\
$\begin{array}{l}\text { C. speobia, } \\
\text { experimental }\end{array}$ & 213 & 246 & 126 & 94 & 155 & 109 & 77 \\
$\begin{array}{l}S . \text { bicornourus, } \\
\text { experimental }\end{array}$ & $\begin{array}{l}\chi^{2} / 6 \\
\text { d.f. }=110.57, \mathrm{P}<.001\end{array}$ \\
$\begin{array}{l}\text { C. speobia, } \\
\text { control }\end{array}$ & 104 & 68 & 45 & 78 & 110 & 102 & 74 \\
$\begin{array}{l}S . \text { bicornourus, } \\
\text { control }\end{array}$ & 155 & 128 & 92 & 70 & 74 & 84 & 101 \\
& $\chi^{2} / 6$ d.f. $=46.59, \mathrm{P}<.001$ & & & \\
\hline
\end{tabular}

TABLE 6. Comparison of animal occurrences within and outside the temperature preferen$\operatorname{dum}\left(18.0^{\circ} \mathrm{C}-21.5^{\circ} \mathrm{C}\right.$ range $)$.

\begin{tabular}{|c|c|c|}
\hline & $\begin{array}{l}\text { Within } \\
\text { range }\end{array}$ & $\begin{array}{c}\text { Outside } \\
\text { range }\end{array}$ \\
\hline C. speobia, experimental & 388 & 764 \\
\hline \multirow[t]{2}{*}{ S. bicornourus, experimental } & 220 & 932 \\
\hline & \multicolumn{2}{|c|}{$\chi^{2} / 1$ d.f. $=62.31 \mathrm{P}<.001$} \\
\hline C. speobia, control & 123 & 1029 \\
\hline \multirow[t]{2}{*}{ S. bicornourus, control } & 162 & 966 \\
\hline & \multicolumn{2}{|c|}{$\chi^{2} / 1$ d.f. $=6.74, \mathrm{P}<.01$} \\
\hline
\end{tabular}


TABLE 7. Relative humidity tolerance data. Shown under "Hours after initial exposure" are the numbers of individuals surviving at the stated number of hours subsequent to their removal from the tolerance apparatus to containers held at $20^{\circ} \mathrm{C}$ and $100 \% \mathrm{R}$. H.

\begin{tabular}{|c|c|c|c|c|c|c|c|c|c|}
\hline \multirow{2}{*}{ Species } & \multirow{2}{*}{$\begin{array}{l}\text { Exposure } \\
\text { (\% R. H.) }\end{array}$} & \multirow{2}{*}{$\begin{array}{l}\text { Duration } \\
\text { of Exposure }\end{array}$} & \multicolumn{7}{|c|}{ Hours after initial exposure } \\
\hline & & & 24 & 36 & 48 & 60 & 72 & 96 & 240 \\
\hline \multirow{4}{*}{$\begin{array}{l}\text { C. speobia, } \\
\text { male }\end{array}$} & $25 \%$ & $12 \mathrm{hr}$. & 9 & 9 & 7 & 7 & 7 & 6 & 6 \\
\hline & $50 \%$ & $12 \mathrm{hr}$. & 17 & 17 & 16 & 15 & 15 & 15 & 15 \\
\hline & $75 \%$ & $12 \mathrm{hr}$. & 20 & 20 & 20 & 20 & 20 & 20 & 19 \\
\hline & $100 \%$ & $12 \mathrm{hr}$. & 20 & 20 & 20 & 20 & 20 & 20 & 20 \\
\hline \multirow{4}{*}{$\begin{array}{l}\text { C. speobia, } \\
\text { female }\end{array}$} & $25 \%$ & $12 \mathrm{hr}$. & 14 & 13 & 13 & 13 & 13 & 13 & 13 \\
\hline & $50 \%$ & $12 \mathrm{hr}$. & 19 & 19 & 18 & 18 & 18 & 18 & 18 \\
\hline & $75 \%$ & $12 \mathrm{hr}$. & 19 & 19 & 19 & 19 & 19 & 19 & 19 \\
\hline & $100 \%$ & $12 \mathrm{hr}$. & 19 & 19 & 19 & 19 & 19 & 19 & 19 \\
\hline \multirow{2}{*}{$\begin{array}{l}S . \text { bicornourus, } \\
\text { sexes mixed }\end{array}$} & $50 \%$ & $4 \mathrm{hr}$. & 13 & 12 & 11 & 11 & 10 & 10 & 10 \\
\hline & $100 \%$ & $4 \mathrm{hr}$. & 20 & 20 & 20 & 19 & 19 & 19 & 19 \\
\hline
\end{tabular}




\section{Tolerance Experiments}

Relative humidity. Table 7 gives numbers of survivors from groups of twenty millipedes after exposure to different relative humidities. There were differences in the ability of male and female cambalids to survive lowered relative humidities but these did not quite approach significance $(\mathrm{P}<.10,>.05$ for $25 \%$ R. H., Table 8$)$. $C$. speobia withstood a twelve hour exposure to $25 \%$ relative humidity with about $50 \%$ survivorship (average of males and females) ten days after exposure. Survival at $50 \%$ for 12 hours was much better (about $80 \%$ survival at the end of ten days), and at $75 \%$ relative humidity, experimentals did not differ from controls. Thus, $C$. speobia cannot be considered stenohygrobic.

$S$. bicornourus is less tolerant than $C$. speobia of the lower relative humidities. This is revealed in two ways: First, there is a significant difference $(\mathrm{P}<.02$ for $50 \%$ R. H., Table 8) in the number of survivors of each species. Second, the data compared are based upon a 12 hour exposure for $C$. speobia but only a four hour exposure for S. bicornourus. Thus, S. bicornourus may be regarded as stenohygrobic.

Temperature. Table 9 shows numbers of survivors from groups of twenty millipedes after exposure to different temperatures. C. speobia was far more tolerant of exposure to $30^{\circ} \mathrm{C}$ and $35^{\circ} \mathrm{C}$ than $S$. bicornourus ( $\mathrm{P}<.001$, Table 10$)$. Again this difference was revealed in spite of much shorter exposure times for $S$. bicornourus. Thus, $C$. speobia is not stenothermic while $S$. bicornourus is. It should also be noted that cambalid males survived exposure to $35^{\circ} \mathrm{C}$ better than did females $(\mathrm{P}<.005$, Table 10).

TABLE 8. Contingency table analyses of relative humidity tolerance data based upon survivorship at 240 hours subsequent to exposure.

\begin{tabular}{|c|c|c|c|}
\hline & & Alive & Dead \\
\hline \multirow{3}{*}{$\begin{array}{l}\text { C. speobia, males vs. } \\
\text { females } 240 \text { hours } \\
\text { after exposure to } \\
25 \% \text { R.H. }\end{array}$} & males & 6 & 14 \\
\hline & females & 13 & 7 \\
\hline & & $\chi^{2} / 1$ d.f. $=3.61, P>05$ & \\
\hline \multirow{3}{*}{$\begin{array}{l}\text { C. speobia vs. S. bicornourus } \\
240 \text { hours after exposure to } \\
50 \% \text { R.H. }\end{array}$} & Cambala & 33 & 7 \\
\hline & Speodesmus & 10 & 10 \\
\hline & & $\chi^{2} / 1$ d.f. $=5.84, P<.02$ & \\
\hline
\end{tabular}


TABLE 9. Temperature tolerance data. Shown under "Hours after initial exposure" are the numbers of individuals surviving at the stated number of hours subsequent to their removal from the tolerance apparatus to containers held at $20^{\circ} \mathrm{C}$ and $100 \% \mathrm{R}$. H.

\begin{tabular}{|c|c|c|c|c|c|c|c|c|c|}
\hline \multirow{2}{*}{ Specics } & \multirow{2}{*}{$\begin{array}{c}\text { Exposure } \\
\left({ }^{\circ} \mathrm{C}\right)\end{array}$} & \multirow{2}{*}{$\begin{array}{l}\text { Duration } \\
\text { of Exposure }\end{array}$} & \multicolumn{7}{|c|}{ Hours after initial exposure } \\
\hline & & & 24 & 36 & 48 & 60 & 72 & 96 & 240 \\
\hline \multirow{3}{*}{$\begin{array}{l}\text { C. speobia, } \\
\text { male }\end{array}$} & 20 & $24 \mathrm{hr}$ & 20 & 20 & 20 & 20 & 20 & 20 & 19 \\
\hline & 30 & $24 \mathrm{hr}$. & 20 & 20 & 20 & 20 & 20 & 20 & 20 \\
\hline & 35 & $7 \mathrm{hr}$. & 16 & 16 & 16 & 16 & 16 & 16 & 16 \\
\hline \multirow{3}{*}{$\begin{array}{l}\text { C. speobia, } \\
\text { female }\end{array}$} & 20 & $24 \mathrm{hr}$ & 20 & 20 & 20 & 20 & 20 & 20 & 20 \\
\hline & 30 & $24 \mathrm{hr}$. & 20 & 20 & 20 & 20 & 20 & 20 & 20 \\
\hline & 35 & $7 \mathrm{hr}$. & 14 & 14 & 12 & 11 & 10 & 6 & 6 \\
\hline \multirow[t]{3}{*}{ S. bicornourus, } & 20 & $15 \mathrm{hr}$. & 20 & 20 & 20 & 20 & 20 & 18 & 18 \\
\hline & 30 & $15 \mathrm{hr}$. & 3 & 3 & 2 & 2 & 2 & 2 & 1 \\
\hline & 35 & $45 \mathrm{~min}$. & 2 & 2 & 1 & 1 & 1 & 1 & 1 \\
\hline
\end{tabular}


TABLE 10. Contingency table analyses of temperature tolerance data based upon survivorship at 240 hours subsequent to exposure.

\begin{tabular}{|c|c|c|c|}
\hline & & Alive & Dead \\
\hline \multirow{3}{*}{$\begin{array}{l}\text { C. speobia, males vs. } \\
\text { females } 240 \text { hours after } \\
\text { exposure to } 35^{\circ} \mathrm{C} \text {. }\end{array}$} & females & 6 & 14 \\
\hline & males & 16 & 4 \\
\hline & \multicolumn{3}{|c|}{$\chi^{2} / 1$ d.f. $=8.182, \mathrm{P}<.005$} \\
\hline \multirow{3}{*}{$\begin{array}{l}\text { C. speobia vs. } \\
\text { S. bicornourus } \\
240 \text { hours after } \\
\text { exposure to } 30^{\circ} \mathrm{C} \text {. }\end{array}$} & Cambala & 40 & 0 \\
\hline & Speodesmus & 1 & 19 \\
\hline & \multicolumn{3}{|c|}{$\chi^{2} / 1$ d.f. $=51.306, P<.001$} \\
\hline \multirow{3}{*}{$\begin{array}{l}\text { C. speobia vs. } \\
\text { S. bicornourus } 240 \\
\text { hours after exposure } \\
\text { to } 35^{\circ} \mathrm{C} \text {. }\end{array}$} & Cambala & 22 & 18 \\
\hline & Speodesmus & 1 & 19 \\
\hline & \multicolumn{3}{|c|}{$\chi^{2} / 1$ d.f. $=12.065, \mathrm{P}<.001$} \\
\hline
\end{tabular}

\section{DISCUSSION}

Cambala speobia and Speodesmus bicornourus show gross responses in relative humidity and temperature gradients for conditions approximating those of their cave environments, findings which are hardly surprising. However, in the details of their responses there are differences, and these are of considerable significance as are their differing abilities to tolerate elevated temperatures and reduced relative humidities.

In brief, the experimental data demonstrate that $C$. speobia is more selective of relative humidities at or approaching saturation and of temperatures closely corresponding to that of the cave than is S. bicornourus. S. bicornourus is less tolerant of elevated temperatures and reduced relative humidities than is $C$. speobia.

Mitchell (1971b) has suggested three questions which may be considered in analyzing troglobite preference and tolerance data. 1) What, if any, relationship exists between the degree of morphological regression of troglobites and their ability to perceive and respond to physical factors of the environment? 2) What are the mechanisms operative in restricting cavernicoles within their optimum environ- 
ment? 3) What are the capabilities of cavernicoles for dispersal in the epigeum?

In response to the first question, morphological regression is more pronounced in $S$. bicornourus than in $C$. speobia. Thus, in these millipe des there is a negative correlation between morphological regression and response to external factors: i.e., the more highly regressed species is less selective. This type correlation was predicted by Mitch ell (1971b), but for cavernicoles which are physically imprisoned in their habitats, primarily aquatics. In the latter type of cavernicole, there would seem to be no selective advantage in maintaining abilities to respond to the varying physical factors of the epigean environment to which it is never exposed. The two species of millipedes in question are not, however, imprisoned within their environment. Their own rnotility gives them the capability of leaving the cave at any time, other things permitting. It is very interesting that of these two millipedes the less tolerant species is at the same time the less responsive. Vandel (1965) would regard these two phenomena as characteristic of phyletic senescence, but this is untenable, since the latter is without any genetic basis for existence.

It does seem plausible that cavernicoles free to leave the cave habitat should possess mechanisms operative in restricting them within their optimal environment (Poulson, 1964; Mitchell, 1971b), and the most obvious mechanisms would seem to be those permitting response to external environmental conditions (or detection of some gradient which would usually exist through a cave opening). This would seem to be especially important for those highly regressed troglobites characterized (or assumed to be characterized in many instances) by severe diminution in their autoregulative abilities. All this assumes that loss of animals through the entrances of caves would be of sufficient importance to place a high selective value on the maintenance and possible elaboration of sensory mechanisms which perceive external factors. It is possible, however, that troglobites are sufficiently removed from the entrances, and the entrances are so small in proportion to the total habitable area of the subterranean system, that the energy expense of maintaining these sensory mechanisms would not be "justified". A consideration of the formation of limestone caves offers, perhaps, some support for this idea.

Limestone caves originate as solution spaces caused by underground waters, and most probably do not acquire entrances of any appreciable size until late in their formation; many subterranean systems unquestionably still lack large entrances. Barr (1968) estimates that $90 \%$ of all caves remain inaccessible to human penetration but adds tha: very few of these are closed to cavernicoles. The obvious inference here is that although no entrance large enough to permit human entry exists, some means of admitting colonizers must have existed in the past, problably small fissures leading from the surface into the cave. Thus, animals "pre-adapted" for cave life, e.g., humicoles, muscicoles, endogeans, etc., must have entered through these obscure fissures and become established in the cave system long before the development of any prominent opening. These small fissures would provide little opportunity for escape to the epigeum, especially if the cave system were large. The cave would, then, be an essentially closed space in which the colonizers could evolve into troglobites. Assuming that most cave entrances were formed fairly recently as a result of roof collapse, erosion by surface waters, or 
whatever, the animals in the cave might well have had ample time to proceed quite far in adaptation to this new environment, including perhaps the loss of certain sensory mechanisms, before again being confronted with the varying, and often rigorous, epigean environment.

It can be seen that Speodesmus bicornourus might have become isolated in these "closed" caves very early, and before large openings developed might have begun to lose the ability to respond to factors variable in the epigeum. Cambala speobia on the other hand may have become isolated later, even after larger cave entrances were formed. Evidence for the greater antiquity of $S$. bicornourus and most of the caves it inhabits will be presented later.

We should not fail to emphasize the fact that these two millipedes were tested for their responses to temperature and relative humidity only. Studies of their responses to other factors might reveal restrictive mechanisms in $S$. bicornourus, although temperature and relative humidity seem intuitively to be among the most likely environmental stimuli to which a terrestrial troglobite might respond.

Preference and tolerance data such as ours permit, perhaps, some insight into the interrelated problems of troglobite dispersal, distribution, and evolution. It is probable that evolution of most terrestrial troglobites in temperate caves was delayed until surface populations of the same species were eliminated by climatic changes (Barr, 1968; Mitchell, 1969). The cave population could then evolve troglobite characteristics, there being now an absence of gene exchange with the surface population. This epigean ancestor of the troglobite would presumably have possessed well developed autoregulative abilities, being exposed to a variable environment. Such abilities would not seem to be of adaptive value in the stable cave environment, and in time they would "regress", as do the more apparent features such as eyes and pigment. Regardless of the precise cause of this regression - this is another and debatable, problem - it is generally accepted that troglobites do, in fact, show more or less reduced autoregulative abilities. The degree of loss of these abilities to compensate for environmental changes might then be used as an index to relative age of the troglobite as is morphological regression (Poulson, 1963). Such an index would be most useful in a rather limited area where it might be assumed that the selection pressures leading to cave adaptation would be similar in kind and intensity, thus avoiding a rate problem (Mitchell, 1969). It also seems plausible that in such an area the extent of speciation within a troglobite genus would be helpful in determinining the relative original times of isolation.

By applying the preceding indices, then, C. speobia would seem to be a much more recent troglobite than $S$. bicornourus. C. speobia retains rather good autoregulative abilities as reflected by its tolerance of elevated temperatures and reduced relative humidities. Additionally, there is but one species of Cambala in central Texas caves opposed to several species of Speodesmus from the same area (Causey, 1960, 1964, pers. comm. to Reddell). It should be mentioned, however, that there is still some uncertainty in the taxonomy of these animals (pers. comm., Causey to Reddell). These phenomena, then, lend support to the conclusion that one would make based upon comparison of morphological features, viz., S. bicornourus is the older of the two troglobites in question. But these temperature and 
relative humidity data permit more than this to be deduced about the evolution of these millipedes.

The distributional data presented in Figs. 3 and 4 show C. speobia to be more widely distributed in central Texas caves than any of the species of Speodesmus, or than of the genus Speodesmus, itself. C. speobia has been reported from 122 caves in 25 counties while $S$. bicornourus is known from only 27 caves in 3 counties. $S$. echinourus is identified from 47 caves in 10 counties. A few undescribed and undetermined species have been taken from 14 caves in eight counties. Although collections in the cave area are still incomplete, a well developed pattern seems to be emerging.

To explain the difference in the present distribution of $C$. speobia and $S$. bicornourus, it is necessary to consider several questions: 1) When did the different caves become available for colonization by surface ancestors? 2) What were the distributions of the surface ancestors? 3) What might have been the temperature and relative humidity responses of the surface ancestors? 4) When were the surface populations eliminated? 5) What are the possibilities for epigean dispersal of the millipedes?

The uplift of central Texas occurred during the Miocene, but exposure of all cavernous limestones did not occur at this time or even simultaneously at any time. Along the Balcones Fault, the faulting itself caused exposure sooner here than in areas away from the fault. In the latter areas, exposure could not occur until removal of overlying late Cretaceous deposits. Fault zone caves might have been available for colonization in late Miocene, but probably not until in the Pliocene or early in the Pleistocene. Other caves were probably not available for colonization until mid-Pleistocene. Whatever may be the absolute times, there is little doubt that caves along the Balcones Fault were colonized prior to those away from the fault (all pers. comm., A. R. Smith to Mitchell; see also Mitchell and R. E. Smith, 1972).

The Balcones Fault Zone extends from Bell County through Williamson, Travis, Hays, Comal, Bexar, Medina, Uvalde, and Kinney Counties, and into Val Verde County. Figs. 3 and 4 show that both Speodesmus and Cambala speobia occur chiefly in caves closely associated with this zone or in those not too far removed from it. Each millipede does, however, occur in some caves distant from the zone, but it is $C$. speobia that is here more common and more widespread. In caves located more than 50 miles from the fault zone, Speodesmus occurs in nine while C. speobia occurs in 28. In caves located along the fault zone or within 50 miles of it, Speodesmus occurs in 77 and C. speobia in 94. A 2 X2 contingency table analysis for heterogeneity of these distributions yields a $\chi^{2}$ of 4.56 with $\mathrm{P}<.05$. It would thus appear that there are real differences in the distributions of these millipedes.

The present day distribution of troglobites is commonly used as an indicator of the past distribution of surface relatives. It is certainly true that present troglobite distributions do, in fact, reflect the broad areas of occurrence of ancestral species, especially on a continental or world-wide basis. However, is it valid to explain small-scale distribution patterns in the same way, the case in point being millipede distribution in caves of central Texas? It might be suggested that the distribution patterns of Speodesmus and C. speobia simply reflect the distributions of the 
ancestors of each. This would presume that $C$. speobia ancestors were widespread in central Texas and that those of Speodesmus were restricted rather closely to an area following the present Balcones Fault. There are no data to support such presumed ancestral distributions. It is actually not necessary to presume peculiar differences in the distributions of the ancestral species; each may just as well be presumed to have had roughly comparable ranges over central Texas.

The temperature and relative humidity tolerance data may be used to suggest a hypothesis in explanation of present $C$. speobia and $S$. bicornourus distributions. Regardless of other causes of the tolerance abilities of $C$. speobia and $S$. bicornourus, the tolerances of these present day species are probably, in part a reflection of the tolerances of the ancestral species of each. If so, the ancestor of Speodesmus, presumably adapted to a more stable microenvironment than ancestral C. speobia, would have been less tolerant of the climatic changes accompanying Pleistocene glaciation and could have early been removed from surface environments. This could well have occurred at such time when the only caves open to colonization were those primarily associated with the Balcones Fault Zone. Thus the majority of the Speodesmus ancestors to survive in central Texas were those which had successfully colonized caves near the Escarpment. Perhaps small disjunct populations of the Speodesmus surface ancestor persisted until some time later in favorable, but isolated, protective, surface microenvironments. The few scattered occurrences of Speodesmus in caves removed from the fault could well represent fortuitous colonizations by such surface relicts.

The ancestral species of $C$. speobia was unquestionably quite tolerant. It is inconcievable that a troglobite would evolve higher tolerances than its surface ancestor because of the environmental stability of the cave. Thus, this ancestral species probably persisted in surface environments in central Texas far longer than did the ancestors of Speodesmus. In fact, $C$. speobia itself is so tolerant, it would not be particularly surprising if it were to be discovered today in some favorable surface habitat. It has, however, never been collected on the surface.

It is possible that the $C$. speobia ancestor began to colonize caves at approximately the same time as did that of Speodesmus. There is nothing to suggest otherwise, and, furthermore, it is not necessary. A more tolerant C. speobia ancestor would populate fault zone caves early, as would the Speodesmus ancestor, but it would persist longer on the surface, long enough to populate the later available caves removed from the fault. The relative abundance of $C$. speobia in these latter caves indicates that the ancestor long occupied surface environments over much of central Texas. During this time speciation was prevented by continued gene exchange between cave and surface populations. During the time of later cave colonizations by the $C$. speobia ancestor, Speodesmus was probably far along in its adaptations to a subterranean environment, its surface ancestor having long since been removed. It seems entirely possible that the surface ancestor of $C$. speobia might not have been eliminated (or effectively eliminated) from the surface until the last interglacial.

Based upon the strong tolerances retained by C. speobia, it would seem that even now it should be able to survive at least temporarily on the surface, thus providing 
the possibility for: use of epigean dispersal routes. After the elimination of the surface populations, many fluctuations in the environment have probably occurred, some of these being compatible with $C$. speobia's tolerances. During these periods C. speobia might have extended its range by dispersal in the epigeum and it might still be doing so. Such dispersal would also provide some degree of gene flow between the various cave populations. So, surface populations of the $C$. speobia ancestor could have been removed earlier than previously suggested, but sporadic use of epigean dispersal routes would still result in the $C$. speobia distribution seen today, as well as the lack of speciation in central Texas Cambala. Climatic conditions were probably never such to permit extensive epigean dispersal by Speodesmus.

We may summarize as follows the sequence of events hypothesized to explain the distribution patterns of Cambala and Speodesmus in central Texas caves.

1. C. speobia and Speodesmus ancestors ranged widely over central Texas by the Miocene.

2. Caves along the Balcones Fault Zone were available for colonization earlier than were caves removed from the fault zone, sometime between late Miocene and early Pleistocene.

3. Fault zone caves were probably colonized at this time by both ancestral $C$. speobia and Speoc'esmus.

4. Early Pleistocene climatic changes associated with glaciation probably eliminated the less tolerant ancestral Speodesmus permitting adaptation to begin early in established cave populations.

5. The range of Speodesmus has probably not been appreciably extended by epigean dispersal.

6. The hardier $C$. speobia ancestor either survived longer into the Pleistocene, at which time it was able to colonize the later available caves removed from the fault zone, or its tolerances permitted sporadic use of epigean dispersal routes resulting in range extension. Either of these, or both in combination, would produce the $C$. speobia distribution pattern seen today.

\section{ACKNOWLEDGMENTS}

We wish to thank Mr. E. O. Beck, owner of Beck's Ranch Cave, for his cooperation in these studies. We are indebted to Mr. James R. Reddell for supplying unpublished locality records of the central Texas cave millipedes and for assisting in compiling the distributional data. We also thank Dr. Nell Causey for information on these millipedes supplied in correspondence to Mr. Reddell. Assisting in various of the field collections were Mr. K. Armstrong, Mr. R. Upton, and Mr. J. Tilly. The junior author is grateful for the productive discussions he has had with Mr. A. Richard Smith on the geology of central Texas. We wish to also thank Mr. Charles Edwards for preparing the fine illustrations of the relative humidity preference apparatus and the temperature preference apparatus. 


\section{SUMMARY}

The temperature and relative humidity preferences and tolerances of two Texas species of cave-adapted millipedes, Cambala speobia (Chamberlin) and Speodesmus bicornourus Causey, were studied. Both species showed gross preferences when tested in gradient chambers for temperatures and relative humidities approximating those of their cave environments. But $C$. speobia, the less adapted species morphologically, was the more selective of the two species for such conditions. S. bicornourus was far less tolerant of elevated temperatures and reduced relative humidities than was $C$. speobia. Discussed is a possible reason why a terrestrial troglobite like $S$. bicornourus would combine intolerance with a lessened ability to perceive those factors to which it is intolerant. Discussed also are the possible causes of the present distribution of Cambala and Speodesmus in the caves of central Texas.

\section{Réactions de deux Diplopodes du Texas adaptés à la vie cavernicole, Cambala speobia (Cambalida: \\ Cambalidae) et Speodesmus bicornourus (Polydes- mida: Vanhoeffeniidae), aux conditions de tempéra- tures et d'humidité relative.}

Les préférendums et les limites de tolérance vis à vis de la température et de l'humidité relative ont été étudiés chez deux espèces de Diplopodes du Texas adaptés à la vie cavernicole, Cambala speobia (Chamberlin) et Speodesmus bicornourus Causey. Mis dans des enceintes où sont établis des gradients de température ou d'humidité relative, les deux espèces montrent des préférendums approchant globalement ceux existants dans leurs grottes d'origine. Cependant C. speobia, Il'espèce la moins adaptée morphologiquement, s'est montrée la plus apte à faire le meilleur choix vis à vis des conditions d'expérience. $S$. bicornourus s'est révélée bien moins tolérante que $C$. speobia aux température élevées et à une humidité relative réduite. Les Auteurs exposent une raison possible pour qu'un troglobie terrestre, tel que $S$. bicornourus, puisse présenter une capacité amoindrie de déceler les facteurs de l'environnement pour lesquels il montre de l'intolérance. De même, les causes possibles de la distribution actuelle des Cambala et Speodesmus dans les grottes du Texas central sont discutées.

\section{LITERATURE CITED}

BARR, T.C., Jr., 1968 - Cave ecology and the evolution of troglobites. In T. Dobzhansky, M.K. Hecht, and W.C. Steere (eds.), Evolutionary biology, 2, 35-102. AppletonCentury-Crofts, New York.

BEAUCHAMP, P. de., 1932 - Turbellariés, Hirudinées, Branchiobdellidés (2ème Série). Biospeologica, 58. Archiv. Zool. Expér. Géner., 73., 113-380.

CAUSEY, N.B., 1959 - Two new troglodytic millipeds from Texas. Proc. Biol. Soc. Washingion, 72, 69-74. 
CAUSEY, N.B., 1960 - Speciation in North American cave millipeds. American Midland Nat., 64, 116-122.

CAUSEY, N.B., 1964 - New cavernicolous millipeds of the family Cambalidae from Texas and Mexico. Int. J. Speleol., 1, 237-246.

CHAMBERLIN, R.V., and R.L. HOFFMAN, 1958 - Checklist of the millipedes of North America. Bull. U. S. Natl. Mus., 212, 1-236.

GINET, R., 1960 - Écologie, éthologie et biologie de Niphargus (Amphipodes, Gammarides hypogés). Ann. Spéléol., 15, 127-237; 238-382.

GLAÇON, S., 1953 -- Recherches sur la biologie des Coléoptères cavernicoles. C.R. 1er Cong. Int. Spéléol. Paris., 3, 39-45.

JEANNEL, R., 1943 - Les fossiles vivants des cavernes. Gallimard, Paris, 321 pp.

MITCHELL, R.W., 1969 - A comparison of temperate and tropical cave communities. Southwestern Nat., 14, 73-88,

MITCHELL, R.W., 1971a - Food and feeding habits of the troglobitic carabid beetle Rhadine subterranea Int. J. Speleol., 3, 249-270.

MITCHELL, R.W., $1971 \mathrm{~b}$ - Preference responses and tolerances of the troglobitic carabid beetle Rhäiine subterranea. Int. J. Speleol., 3, 289-304.

MITCHELL, R.W., and R.E. SMITH, 1972 - Some aspects of the osteology and evolution of the neotenic spring and cave salamanders (Eurycea, Plethodontidae) of Central Texas. Texas J. Sci, 23, 341-362.

PERTTUNEN, V., 1953 - Reactions of diplopods to the relative humidity of the air. Ann. Zool. Soc. Vanama, 16, 1-59.

POULSON, T.L., 1963 - Cave adaptation in amblyopsid fishes. American Midland Nat., 70, 257-290.

POULSON, T.L., 1964 - Animals in caves. In D.B. Dill (ed.), Handbook of physiology, Sec. 4, 749-771. American Philosophical Soc., Washington, D.C.

REDDELL, J.R., 196.5 - A checklist of the cave fauna of Texas. I. the Invertebrata (exclusive of Insecta). Texas J. Sci., 17, 143-187.

REDDELL, J.R., 1970 - A checklist of the cave fauna of Texas. IV. additional records of Invertebrata (exclusive of Insecta). Texas J. Sci., 21, 389-415.

SZYMCKOWSKY, W., 1953 - Preferendum termiczne jaskiniswego pajaka Meta menardi Latr. (Argiopidae). Folia Biol. Warzawa, 1., 3.

VANDEL, A., 1965 - Biospeleology, the biology of cavernicolous animals. Pergamon Press, New York. 524 pp. 